Management House, 8 Hill Street, London, W.1, or from any of the above universities or colleges; the forms should be returned to the Secretary of the Institute not later than January 31 .

\section{International Exchange of Students for Technical Experience}

THE sixth annual report of the International Association for the Exchange of Students for Technical Experience (pp. 66; from the Association, Imperial College of Science and Technology, London, S.W.7 ; November 1953) records a smaller increase (290) in the international exchange than during 1952. With a total of 3,783 students exchanged, the excessive proportion of students withdrawing after nomination causes much unnecessary labour both to industries and to the administration of the Associa. tion. The report rightly emphasizes that national committees should make every effort to ensure that students nominated are made aware of their obligations to industry by completing the full period of training offered abroad. The administration of the exchange in some of the seventeen member countries still leaves much to be desired, and the benefit derived by a member country depends largely on the energy and efficiency with which it carries through the work of the Association. Nevertheless, during 1952 the Association was able to exchange 3,493 students at an administrative cost per student, including the printing of the fifth annual report, of 3s. 1d. During 1953, 241 institutions in soventeen countries and twenty-seven faculties participated, as compared with seventy-three from ten countries and nineteen faculties during 1949, while the students were received by 1,733 institutions, compared with 550 in 1949 and 1,460 in 1952. Mechanical, electrical and civil engineering, mining, chemical engineering and chemistry, in that order, provided by far the largest number of students, and, with the exception that chemistry and chemical engineering changed places, the corresponding industries provided the great majority of places. More students were accepted. than were sent in the following countries (excess given in brackets): Sweden (289), Great Britain (79), Switzerland (39), Canada (22), Norway (11), Germany (9) and Iceland (4). Of countries sending more students than they accept, Austria (160), Israel (58), Denmark (53), Yugoslavia (37), Finland (35), Belgium (29) and France (29) show the largest excesses. A list of institutions and firms participating in the scheme is given under each country. Great Britain sent abroad, in 1953, 544 students from twenty-seven universities and colleges, an increase of fifty-six over 1952, and received 623 students, an increase of twenty-one; about fifty places were not taken up.

International Union of Crystallography:

Congress in Paris

THE Third General Assembly and International Congress of the International Union of Crystallography will be held in Paris during July 21-28, 1954. Delegates to the General Assembly, which will be concerned with the formal business of the Union, will be nominated by the national committees, but the International Congress is open to all crystallographers. The membership fee will be 3,000 francs for crystallographers and 2,000 francs for their friends. The subjects to be considered at the Congress will be as follows: instruments and measurements; new developments in structure determination; mineral structures, including synthetic minerals and ceramics; metal structures; inorganic structures; organic structures; proteins and related structures; random and deformed structures; liquids and liquid crystals; glasses; thermal transformations ; diffuse scattering; crystal growth ; neutron diffraction; and miscellaneous. No report of the Congress will be published, but full abstracts of the contributions will be distributed in advance. Those intending to read papers should send an abstract of about twenty-five words to the programme committee as soon as possible (in any case not later than February 15) and, if accepted, more detailed abstracts will be required before March 31 . The three official languages of the Congress are English, French and German. As well as the papers on the above topics, a number of survey lectures will be arranged on subjects of general crystallographic interest. In addition, there will be two symposia after the Congress, during July 29-30, as follows : the location and function of hydrogen; and the mechanism of phase transitions in crystals. These symposia are intended for specialists, but all crystallographers will be welcome and introductory sessions will be arranged during July 21-28. In conjunction with the Congress an exhibition will be held of materials, apparatus, books, literature, etc., related to crystallography. Enrolments for the various meetings or space at the exhibition should be submitted on the appropriate form before February 15, and such correspondence together with all other matters concerning the Congress and the symposia should be addressed to the secretary of the local committee and of the programme committee, A. J. Rose, Laboratoire de Minéralogie, 1 rue Victor Cousin, Paris 5e. Correspondence relating to the General Assembly and the business of the Union should be referred to the general secretary, R. C. Evans, Crystallographic Laboratory, Cavendish Laboratory, Cambridge.

\section{World Power Conference Sectional Meeting}

A Sectronal Meeting of the World Power Conference will be held in Rio de Janeiro during July 25-August 8, 1954. The conference proper will be held during July 25-31, and the papers will deal with the following seven subjects : planning of the electric power industry; the electric power industry in tropical and sub-tropical regions; natural and derived fuels; wind power; solar energy ; uses of electric power; and international hydro-electric developments. During the following week the Brazilian National Committee will organize tours in which a number of hydro-electric stations, hydro and thermal plants, and petroleum installations, as well as places of cultural interest, will be visited. British persons who wish to participate should write at once to the Secretary, British National Committee, World Power Conference, 201-2 Grand Buildings, Trafalgar Square, London, W.C.2.

\section{Chemistry and Industrial Applications of Cellulose :}

\section{Symposium at St. Andrews}

IN 1947 and 1949 the Royal Institute of Chemistry held at the University of St. Andrews two symposia dealing respectively with recent developments in the organic chemical industry and in the fermentation industries. The success of these meetings has encouraged the Scottish Sections of the Institute to arrange a further symposium, to be held in the University during June 28-July 2, at which comprehensive reviews of recent advances in the 